\title{
THE USE OF MODAL AUXILIARY VERBS IN REPORTING COVID-19: A STUDY OF SELECTED ARTICLES DAILY NATION NEWSPAPER
}

\author{
Odhiambo Kenneth ${ }^{1 凶}$, Owala Silas Odhiambo ${ }^{2 区}$ \\ 1,2 (Ph.D.) Department of Language, Literature and Culture Maasai Mara University, Kenya
}

DOI: https://doi.org/10.29121/granthaalayah.v8.i7.2020.550

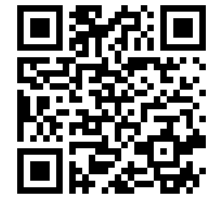

Article Type: Research Article

Article Citation: Odhiambo

Kenneth, and Owala Silas Odhiambo. (2020). THE USE OF MODAL AUXILIARY VERBS IN REPORTING COVID-19: A STUDY OF SELECTED ARTICLES DAILY NATION NEWSPAPER. International Journal of Research -GRANTHAALAYAH, 8(7), 118-129.

https://doi.org/10.29121/granthaa layah.v8.i7.2020.550

Received Date: 21 June 2020

Accepted Date: 27 July 2020

Keywords:

Modal Verbs

Covid-19

Newspaper Articles

Daily Nation

\begin{abstract}
This article analyses the uses of modal auxiliary verbs in reporting Covid-19 in selected articles in Daily Nation newspaper. Covid-19 is a member of the beta coronaviruses that can cause acute severe respiratory symptoms or possibly mild, cold-like symptoms. The reporting of the disease was done in the newspaper in Kenya every day from the first time it was reported in the country on 13th March 2020. The articles analyzed were purposively selected from articles in Daily Nation newspaper and analyzed using insights from Quirk et al's (2000) dichotomy of modal auxiliary verbs. The data was analyzed manually with regard to different functions of the modal auxiliary verbs in question. Six categories of modal auxiliaries namely; Ability, possibility, prediction, obligation, intention and quasi-legal modals characterized the data. Findings indicate that the authors of the articles chose predictive auxiliary modals will, may, can and should in that order in the articles. Other types of modal used are would, must and might. The modals used presented the opinions of the article writers and the use of will reported the highest frequency.
\end{abstract}

\section{INTRODUCTION}

This paper sets to analyse modal auxiliaries and how they are used in reporting Covid-19 in Daily Nation newspaper in Kenya. There are various definition of the term modal auxiliaries. Halliday (1970) regards modality as the way that makes it possible for the speaker to interfere and take up a viewpoint in the speaking incident Quirk, Greenbaum, Leech, \& Svartvik, (1985) assert that modality is how speakers decide on the genuineness of the topic. These definitions indicate a non-conclusiveness in the notion of modality. Modality is extremely important in written discourse as it conveys the writer's attitude both to the propositions he/she makes and to the readers. Hyland (1994) states that the ability to use modality appropriately also contributes significantly to pragmatic aspect in English writing and influences the way a reader responds to the content of the writing. The purpose of this paper is to analyse the use of modal auxiliaries in reporting Covid-19 in Daily Nation newspaper to show how article authors show the opinion of covid-19.The leading questions are: What are the modals auxiliary verbs used in Daily Nation newspaper articles on Covid-19?; What is the most frequent modal used in Daily Nation newspaper articles on Covid19; What is the use of the modal auxiliary verbs in Daily Nation newspaper articles on Covid-19?

(C) 2020 The Author(s). This is an open access article distributed under the terms of the Creative Commons Attribution License, which permits unrestricted use, distribution, and reproduction in any medium, provided the original author and source are credited. 


\subsection{MODAL AUXILIARY VERBS}

In this section we will revisit the definition of modal auxiliaries and show their functions from a broad perspective. Radford, Atkinson, Britain, Clahsen, \&Spencer, ((1999) state that auxiliary verbs are verbs that precede the lexical verb and are perform various semantic functions. In this case therefore the auxiliary verb gives the lexical verb additional meaning. According to Huddleston \& Pullum (2005) modality is defined as the speaker's verdict about the "necessity" and "possibility" of subjects. Leech (1987) avers that modals are used in writing and speaking, to express issues which are related to form opinions, understandings, purposes, obligations, free will and other associated notions. From these definitions it can be deduced that modals speak for the writer/speaker in terms of what the writer/speaker thinks as important in the message to be put across. Modals can be indicated with the forms below:

1) This disease will cause suffering to many. (Will)

2) The virus could be airborne. (Could)

3) We must protect ourselves against this virus. (Must)

Modal auxiliary verbs, therefore, have several functions and one modal may have various meanings and one meaning can also be related to various modal forms. On the basis of Quirk \& Greenbaum, (2000 p.52 - 56) description of modal auxiliaries this paper pursues the possible functions which every modal could impart.

Table 1: Quirk et al.'s (2000) Description of modal auxiliaries

\begin{tabular}{|c|c|c|c|}
\hline & Modal & Use & Example \\
\hline \multirow[t]{5}{*}{1} & Can & Ability & He can speak English. \\
\hline & & Permission & \\
\hline & & -be allowed to & Can I smoke here? \\
\hline & & -be permitted to & \\
\hline & & Theoretical possibility & $\begin{array}{l}\text { The road can be blocked (It is possible to block } \\
\text { the road). }\end{array}$ \\
\hline \multirow[t]{4}{*}{2} & Could & Past ability & I never could play banjo. \\
\hline & & Present or future permission & Could I smoke here? \\
\hline & & Present possibility (theoretical or factual) & $\begin{array}{l}\text { We could go to the concert } \\
\text { The road could be blocked. }\end{array}$ \\
\hline & & $\begin{array}{c}\text { Contingent possibility or ability in unreal } \\
\text { conditions }\end{array}$ & If we had more money, we could buy a car. \\
\hline \multirow[t]{3}{*}{3} & May & Permission & \\
\hline & & -Be allowed to & You may borrow my car if you like. \\
\hline & & Possibility (usually factual) & $\begin{array}{c}\text { This road may be blocked. (It is possible that this } \\
\text { road is blocked). }\end{array}$ \\
\hline \multirow[t]{2}{*}{4} & Might & Permission (rare) & Might I smoke in here? \\
\hline & & Possibility (theoretical or factual) & $\begin{array}{l}\text { We might go to the concert. } \\
\text { What you say might be true. }\end{array}$ \\
\hline \multirow[t]{4}{*}{5} & Shall & Willingness (on the part of the speaker) & $\begin{array}{l}\text { He shall get his money. } \\
\text { You shall do exactly as you wish. }\end{array}$ \\
\hline & & $\begin{array}{c}\text { Intention (on the part of the speakers only in Ist } \\
\text { person) }\end{array}$ & $\begin{array}{l}\text { I shall let you know our decision. } \\
\text { We shall overcome. }\end{array}$ \\
\hline & & a) Insistence (restricted use) & You shall do as I say. \\
\hline & & b) Legal and quasi-legal injunction & $\begin{array}{l}\text { The vendor shall maintain the equipment in good } \\
\text { repair. }\end{array}$ \\
\hline \multirow[t]{3}{*}{6} & Should & Obligation and logical necessity & $\begin{array}{l}\text { You should do as he says. } \\
\text { They should be home by now. }\end{array}$ \\
\hline & & "Putative" use after certain expressions & It is odd that you should say this to me. \\
\hline & & Contingent use & We should love to go abroad. \\
\hline
\end{tabular}


The Use of Modal Auxiliary Verbs in Reporting Covid-19: A Study of Selected Articles Daily Nation Newspaper

\begin{tabular}{|c|c|c|c|}
\hline & & In rather formal real conditions & $\begin{array}{l}\text { If you should change your mind, please let us } \\
\text { know. }\end{array}$ \\
\hline \multirow[t]{7}{*}{7} & \multirow[t]{7}{*}{ Will } & Willingness. Used in polite requests & $\begin{array}{c}\text { He'll help you if you ask him. } \\
\text { Will you have another cup of coffee? }\end{array}$ \\
\hline & & Intention & I'll write as soon as I can. \\
\hline & & Insistence & He will do it, whatever he says. \\
\hline & & Prediction & \\
\hline & & -Specific prediction & The game will be finished by now \\
\hline & & -Timeless prediction & Oil will float on water. \\
\hline & & -Habitual prediction & $\begin{array}{l}\text { He will always talk for hours if you give him the } \\
\text { chance. }\end{array}$ \\
\hline \multirow[t]{5}{*}{8} & Would & Willingness & Would you excuse me? \\
\hline & & Insistence & $\begin{array}{l}\text { It's your own fault; you would take the baby with } \\
\text { you. }\end{array}$ \\
\hline & & Characteristic activity in the past & Every morning he would go for a long walk. \\
\hline & & $\begin{array}{l}\text { Contingent use in the main clause of a } \\
\text { conditional sentence }\end{array}$ & He would smoke too much if I didn't stop him. \\
\hline & & Probability & That would be his mother. \\
\hline \multirow[t]{2}{*}{9} & Must & Obligation/Compulsion & You must be back by 10 o'clock \\
\hline & & Necessity (Logical) & There must be a mistake. \\
\hline
\end{tabular}

From Table 1 above, modals can be summarized into three categories based on their major uses as:

1) "permission/ possibility/ ability": - can, could, may, might

2) "obligation/necessity": - must, should

3) "volition/ prediction": - will, would, shall"

It can also be noted that the same modal sometimes are used to express different functions like that of "probability", "possibility" and "certainty", and "ability", "permission" and "obligation".

Downing and Locke (1992) aver that modality appears as a linguistic feature generated by a variety of linguistic phenomena among which modal verbs play a special role. Modal auxiliaries are divided into two groups: epistemic and deontic.

According to Huddleston and Pullum (2005), epistemic modality expresses meanings relating primarily to what is necessary or possible given what we know (or believe). This can be paraphrased as that type of modality that is related to judgment and expressing judgment on whether something is or is not the case. E.g. He may be telling a lie.

Deontic modality is the second category of modality. The meaning of deontic modals is related to permission or obligation, rather than possibility and necessity. Palmer (1990) distinguishes between epistemic and deontic modality stating that the two uses of the modals are essentially making a judgment about the truth of the proposition, the other being concerned with influencing actions, states or events. These kinds of 'influencing actions', states or events have to do with permission and obligation that is being laid upon the referred individual or thing, E.g. Social distancing must be observed.

The purpose of this paper is to analyze the use of modal auxiliaries in reporting Covid-19 in Daily Nation newspaper to show how article authors represent opinion about Covid-19.

\subsection{THE COVID-19}

The 2019-nCoV or H-CoV-19 virus (now dubbed SARSCoV-2) is a member of the beta coronaviruses and can cause acute severe respiratory symptoms or possibly mild, cold-like symptoms (Cheng and Shan 2020). Its epidemiological characteristics have hampered the establishment of a better classification of the disease. The peculiar genetic features of the virus which enabled it to potentially jump across different species-putatively from bats or pangolins to humans (Andersen, Rambaut, Lipkin, Holmes and Garry. 2020) - have effectively facilitated its rapid spread (Cheng and Shan 2020)

According to WHO Situation Report-59 released on 19 March 2020 (The World Health Organization 2020), the second 100,000 Covid19 cases were confirmed within the last 12 days in March, whereas the first 100,000 cases 
Odhiambo Kenneth, and Owala Silas Odhiambo

were confirmed over the first three months of the pandemic that is January 2020 to March 2020. This indicates the severity of the disease as well as its spread among humans.

Kenya had its first Coronavirus case confirmed and reported on 12th March 2020. Since then there has been a rapid rise in the disease infection. The government of Kenya then gave a raft of measures to contain the spread of the disease. The media became active in disseminating the government protocols in order for its citizens not to contract and spread the disease. It is against this effort by the media to disseminate Covid-19 information that this article seeks to examine the use of modal auxiliaries in Daily Nation Newspaper coverage to show the authors' opinion about Covid-19.

\subsection{NEWSPAPERS IN KENYA}

There are several newspapers that report issues of Covid19 in Kenya. These include The Standard, The Star, The People Daily and Daily Nation. The Daily nation newspaper was started in the year 1958 as a Swahili weekly called 'Taifa' by an Englishman Charles Hayes. It was bought in 1959 by the Aga Khan and became a daily newspaper. According to Wikipedia an English language paper edition called Daily Nation was published on 3rd October 1960. The newspaper is published by the Nation Media Group from its headquarters at Nation Center on Kimathi Street in Nairobi.

According to Ngoge (2014) Daily Nation and its sister publication Sunday Nation had a market share of 53\% in 2011 and 74\% in 2013. This therefore makes Daily Nation a leading Newspaper in Kenya and hence the choice to use the articles published in it for this paper.

Daily Nation is a media and media has a major influence in the understanding and perception of the world people live in, when they use a specific language. In effect, this language is not highly authentic enough since it is used and administered by dominant world-views of the writers. Fowler (1991) states that the world of the press is not the real world, but a world skewed and judged. In other words, the writer uses language in order to influence the perception of readers. In this particular case the article writers use modal auxiliaries to influence the perception of readers as regarding the severity of Covid-19. Hodge and Kress (1993) to this end posit that the language of the press then presents a perception of 'reality' in the form which it regards as most suitable for its readership thus implying keeping the power of media discourse hidden from the mass of the population is a natural tendency in journalism.

Media centers play an important role not only in public opinion building but also in decision-making by the readers. Therefore, the articles written about Covid-19 by Daily Nation media are important in shaping the opinion of the readers in response to the Covid-19 pandemic. Particular attention, then, is paid on the choice of modal auxiliaries in the articles that enhances the opinion of the authors about Covid-19.

In this context, Daily Nation newspaper is considered to be important regarding its function and readership coverage throughout the country for a long time Ngoge (2014). The news articles about Covid-19 are not just coverage of news events but also comments on events and contain background information, explanations, interpretations as well as opinions on Covid-19. The articles could be seen as a conscious expression of the newspaper's position on Covid-19. It could be seen as the voice of the newspaper, seeking to inform, admonish, influence, appeal and motivate readers concerning Covid-19. The voice of the newspaper reporters drives the researchers in situating this paper within modal auxiliary framework to show the author's opinion about Covid-19.

\subsection{STUDIES ON MODAL AUXILIARY VERBS}

There is a huge number of studies in modality and this indicates how rich the field is. The studies have ranged from the use auxiliary verbs by students of English as a Second Language and English as a Foreign Language to the use of modal auxiliary verbs in journals, with each focusing on different perspectives of the modal auxiliary verbs.

Ling (2016) studied the use of modal auxiliary verbs in Horoscope. Horoscope is a regular content in women's magazine. This study takes the background that modal auxiliary verbs are among the most problematic grammatical items in teaching and learning of English.The study is a corpus-based approach which seeks to investigate word frequency and examine the use of modal auxiliary verbs in the Horoscope section of English women's magazines. The data were analyzed using AntConc and Editpad Pro to generate frequency lists and concordance lines. It was found that the most frequent modal auxiliary verbs used in horoscope are will and may to express prediction and possibility. The least used modal auxiliary verbs are should and must which are modals of necessity and obligation. 
The pronoun you is the most frequent lexis in every Horoscope entry. Based on findings from this study, Horoscopes can be used to teach the modal auxiliary verbs in addition to prescribed Malaysian text books. This study does not also seek to use modal auxiliary verb for pedagogical purposes but to report on journalists' opinion of Covid-19.

Torabiardakani et. al, (2015) researched on modal auxiliaries and their semantic functions used by advanced EFL learners. They state that since modal auxiliary verbs have been proved to be one of the most troublesome grammatical structures in English, they decided to do an analysis on the ways in which advanced Iranian EFL students use modal auxiliaries focusing specially on nine modals' semantic functions. To do this, a learner-corpus was constructed with 136 compositions written by Iranian learners and then Wordsmith Tool was used to analyze this computerized data. The results of this study are that some meanings are overly used (like "ability" meaning of can) and some of them are not really used by Iranian learners like the "possibility" meanings of can and could. According to them, it is very important to draw Iranian learners' attention to other pragmatic functions of modals.

Yang (2018), undertook a corpus-based study of modal verbs in Chinese learners' academic writing. The two main research questions in this study were twofold: to find the differences in the use of modal verbs in the learner and professional corpora and the possible causes that account for these differences. The study adopted a corpusbased approach comparing data from two corpora: the Chinese learner writers' corpus and the professional writers' corpus. The results suggested that Chinese learners of English tend to use modal verbs more than professional writers. They are also found to overuse modal verbs including can, will, would and could and underuse the modal verb may.

Logogye (2016) studied how modal and lexical verbs are used to perform speech functions in the editorials of two Ghanaian newspapers. This was done with the aim of identifying the distribution of modal auxiliaries and lexical verbs and their speech acts in the data. An interesting finding is that the use of will, should, must dominate the other modals in expressing speech acts. The modal auxiliaries mostly help in passing on information. With regards the modal lexical verbs, the editors are indiscriminate in their choice. It is observed that every lexical verb is worthy enough to perform speech acts.

Ahmad et al, (2019) examined the use of different modal verbs for the purpose of personal stance marking in Pakistani English newspaper editorials. The results show that the modals of prediction (will, would) are most extensively used in Pakistani English newspaper editorials which further means that prediction is the characteristic feature of the said editorials. In addition, Pakistani editorialists have been found to report information about news events with personal as well as institutional judgements and stances which have been realized through the use of different modal verbs. Moreover, the editorialists have also been found to use the said verbs to maintain their authorial persona, make the readers align with their personal or institutional views and thereby manipulate their opinions in favor or against the state of affairs. The study suggests that the readers of Pakistani English newspaper editorials should be conscious of the fact that the editorials might be biased and affect their opinion.

Sadia \& Ghani (2019) studied modality in editorials of Pakistani English Newspapers. They aver that modality is an important grammatical expression which finds its expression in the editorial section of newspapers in Pakistan. The study focused on how the modal verbs in Pakistani English newspapers are used to manipulate readers' opinion towards specific issues. For this purpose, a corpus of two Pakistani English newspapers: The Dawn and The News, equally divided by editors, was analyzed. The comparative analysis of these newspapers revealed that both the editors chose mainly predictive auxiliary modals such as will and would to the other types of modal. The predictive modal for The News suggested that prediction about the future "what will/would happen" was the major apprehension of the editorial writers. On the other hand, comparing the modals of obligation in the two newspapers, The Daily Dawn was more focused on solution-what should be done. This study focused on editorials which is the diverging point with the current paper which will analyze modals in articles.

\section{METHODOLOGY}

This research was designed to analyze modal auxiliary used, their frequency, and the uses of modal auxiliary verbs in Daily Nation Newspaper. It used a purposive design to select the newspapers articles for the period $1^{\text {St }}$ April to $30^{\text {th }}$ April 2020. For the purpose of this paper the data was drawn for the period $1^{\text {st }}$ to $10^{\text {th }}$ April as this formed the pilot project for data collection. It is the wider research that will use the data collected for the whole period. This was the first month in which Covid-19 was gaining it spread and it was therefore worth studying how the newspaper articles were using auxiliary verbs in presenting the opinion of article authors about Covid-19. 
This research is corpus-driven. Tognini-Bonelli (2001) notes that a corpus-driven approach is a methodology whereby the corpus serves as an empirical basis from which lexicographers extract their data and detect linguistic phenomena without prior assumptions and expectations. Any conclusions or claims are made exclusively on the basis of corpus observations. The corpus for this research was modal auxiliary verbs extracted from Daily Nation newspaper for the period stated above.

\subsection{DATA ANALYSIS}

The study is essentially a qualitative content analysis. Content analysis is a methodological strategy that enables researchers to understand the process and character of social life and to arrive at a meaning, and it facilitates the understanding of the types, characteristics and organizational aspects of documents as social products in their own right as well as what they claim.

The corpus of this paper has been analyzed in the light of functional approach by Quirk et al (2000) which helps analyze the function and types of modality. The data was analyzed manually with regard to different functions of the modal auxiliary verbs in question. The uses of modals in this paper are derived from Quirk et al (2000) schema of modal auxiliaries The analysis was also guided by our research questions which were: what is the most frequent modal used in Daily Nation newspaper articles on Covid-19 and what is the use of the modal auxiliary verbs in Daily Nation newspaper articles on Covid-19?

\section{RESULTS AND DISCUSSION}

The analysis of data collected from the articles in Daily Nation reveals that all the nine central auxiliary verbs were used. These auxiliaries were: can, could, will, would, may, might, shall, should and must. The negations of the auxiliary verbs used were five. These were: should not, might not, may not, will not and cannot. This indicates that the article authors use a variety of modals to pass their messages to the readers.

\subsection{FREQUENT MODAL AUXILIARY VERBS IN DAILY NATION}

The data of the modals in Daily Nations collected and analyzed show different distribution of frequency in modal auxiliary verbs.

Table 2: The distribution of modals in corpus

\begin{tabular}{|c|c|c|}
\hline Modal & Frequency & Percentage \\
\hline WILL & 61 & 28.9 \\
\hline MAY & 28 & 13.3 \\
\hline CAN & 25 & 11.8 \\
\hline SHOULD & 25 & 11.8 \\
\hline WOULD & 20 & 9.4 \\
\hline COULD & 20 & 9.4 \\
\hline MUST & 11 & 5.2 \\
\hline SHALL & 08 & 3.8 \\
\hline MIGHT & 04 & 1.9 \\
\hline CAN NOT & 03 & 1.5 \\
\hline MAY NOT & 02 & I.0 \\
\hline WILL NOT & 02 & I.0 \\
\hline MIGHT NOT & 01 & 0.5 \\
\hline SHOULD NOT & 01 & 0.5 \\
\hline TOTAL & 211 & 100 \\
\hline
\end{tabular}

The Table above reveals interesting patterns in data. All nine central modal verbs are used in Daily Nation articles on Covid-19. There are also five negatives of the modals that are used. The data also shows a significant 
The Use of Modal Auxiliary Verbs in Reporting Covid-19: A Study of Selected Articles Daily Nation Newspaper

difference in the use of the various modal verbs. The modal verb will is greatly used by the authors compared to the other modal verbs. Will accounts for 28.9 per cent of total modal verbs used. The least used modal verb form is might that accounts for 1.9 per cent of the total modal verbs. . Some modal verbs are used far more frequently than others. The most frequent modal verbs of all in Daily Nation is the modal verb will. All the modal verbs (will, would, can, could, shall, should, may, might and must) in the newspaper.

The modal auxiliary may is the second most modal auxiliary verb used. It accounts for $13.9 \%$ of all the modal verbs in the data. On the other hand, shall and might are the least frequent modal verb used. Shall accounts for 3.8\% and might accounts for $1.9 \%$. The results of this corpus analysis are meant to show how often, and in which meanings the different modals are used in written articles about Covid-19.

The frequencies show us that will and may that are prominent in the articles about covid 19. In this case the modal will is more prominent in reporting Covid -19 than other modals. The modal auxiliary verb will has the highest frequency compared to other modal auxiliary verbs. This is similar to the findings by Ling, (2016) who reported that the modal will accounts for almost $2.69 \%$ of all modal verbs in the Horoscope magazine. Although in Ling's study will accounts for $2.69 \%$, it is still the most frequently used modal in the analysis.

On the basis of frequency data it is possible to see which modals are the most salient ones and should thus be used in the portrayal of opinion about Covid-19.In this case the use of will which accounts for $28.9 \%$ and may which accounts for $13.3 \%$ should be used as they portray opinion about covid-19 as the authors intend. The fact that the use of will and may modal verbs is more frequent than others substantiates the point that modal auxiliary verbs are contextually deployed to achieve specific communicative intents of the author's as shown in the functions of modal auxiliary.

Palmer (2007), states that modal auxiliary verbs help language users express 'what should be', 'what may be', 'what would be', and 'what is'. Thus, the authors of the articles make frequent use of modal verbs to show possibility, necessity and prediction in their writing. As the results in the frequency table indicates, the authors of articles on covid-19 use more will to indicate prediction. Will accounts for $28.9 \%$ of the modal auxiliary used and this is the highest percentage. Modality involves the claims or assertions of a person assuming the position of authority and claiming or asserting to have the knowledge of what will happen in future. On this basis the results given the use of modal auxiliary will indicates what will happen in future.

\subsection{THE FUNCTIONS OF MODAL AUXILIARY VERBS}

Having collected the frequency data, the data was analyzed manually with regard to different functions of the modal auxiliary verbs in question. Uses of modals in this paper are derived from Quirk et al (2000) schema of modal auxiliaries.

A total of 211 modal auxiliary usages are recorded in the data. A few of these modal auxiliaries are randomly picked for the purpose of discussing their functions. Examples of modal auxiliaries used in the context of the selected articles of this work are listed below for the discussion:

\subsubsection{ABILITY}

"Ability" in the sense of this study is based on the capability of an agent to perform actions. The examples listed below are textual illustrations from the newspaper articles showing the use of can, could and may to indicate ability. The excerpts below are from Daily Nation.

1) A panel of advisers to the WHO is set to determine whether the virus can be projected further than previously thought.

2) The virus can live for up to four hours on copper, $24 \mathrm{hrs}$ on cardboard and up to 2-3 days on some surfaces like plastic and steel.

3) It is an enemy that can easily convince you that life can continue as normal

4) The virus could be airborne making social distancing and wearing of masks a critical way to keep safe.

5) The virus could be suspended in the air for minutes causing risk of infection through breathing.

6) Covid-19 patients, even those who are only mildly ill, may create aerosols of virus and contaminate surfaces that may pose a risk for transmission.

7) The widespread use of face masks may have played a role in containing the break. 
The modal auxiliary may has been used 28 times in the articles, representing a total of $13.3 \%$. Thus, it occurs quite frequently in the articles. As a modal verb in the articles, may is used to expresses ability. It is used to express ability in sentences 6 and 7 .

In sentence 6, may indicates that patients of covid- 19 have the ability of infecting other people by producing aerosols. In sentence 7, may indicates that the use of masks had the ability to contain the spread of covid-19.

Can has been used 25 times in the articles, representing a total of $11.8 \%$. As a modal verb in the articles, can is used to expresses ability. It is used to express ability in sentences 1, 2 and 3 .

In sentence 1, can is used to show the ability of the virus to be projected further than previously thought. In sentence 2 , it is used to indicate that the virus has the ability to stay longer on different surface materials and in sentence 3, it indicates that it has the ability to make one lead a normal life even though it is dangerous.

Could has been used 20 times in the articles, representing a total of $9.4 \%$. As a modal verb in the articles, can is used to expresses ability. It is used to express ability in sentences 4 and 5 . In sentence 4, could suggests that the virus has the ability to be airborne and in sentence 5 , it has the ability to be suspended in the air for several minutes.

Leech and Coates (1980), state that ability implies possibility, which means that if someone has the ability to do something, then it is possible to perform that action. This type of function is shown in excerpts $1-7$.

\subsubsection{POSSIBILITY}

"Possibility" meaning refers to the fact that something might exist though there is no certainty (Leech \& Coates 1980). Modal can, could, may and might shows possibility as reflected in the following examples are taken from Daily Nation.

8) Delay of implementation of protocols can compromise the quality of healthcare.

9) It is an enemy that can easily convince you that life can continue as normal.

10) The toilet facilities had evidence of the virus and that sharing such facilities could lead to infections.

11) Don't wait to hear someone you know has died, that someone could be you.

12) To have rapid testing kits to help us where we may not be able to test suspected cases using the current system.

13) Delay of implementation of protocols can compromise the quality of healthcare and may lead to unnecessary deaths.

14) Many fear that they might have contracted the disease in the facility.

15) Masks are a physical barrier that keeps away tiny organisms or microbes that a sick person might expel in the environment

In the data, the modals can, could, may and might are used to indicate possibility. Sentences 8-15 are the contextual use of the four modals.

Sentence 8 can is used to expresses the possibility quality of healthcare can be compromised when there is a delay in the implementation of protocols. In sentence 9, can indicates that the possibility of continuing with life as normal is high even with the spread of Covid-19. This is because Covid-19 is equated to an invincible enemy which would attack one unawares.

In the data, could has a frequency rating of 20 and a percentage of $9.4 \%$. In the articles, could is used to express possibility. In sentence 10, it indicates that there is a possibility of the virus staying in the toilet and therefore infecting the users when shared and 11 the virus is a killer virus and there is a possibility of one being killed by the virus. In sentence 13, the use of may suggests that there is a possibility of unnecessary deaths.

In sentence 14, might suggests a possibility of contracting covid-19, in health facilities and in sentence 15, might suggests that there is a possibility that sick persons expel microbes into the air.

The use can, could may and might as possibility accounts for the fact that the articles show the lack of certainty regarding certain aspects. In sentence 8, the lack of certainty is delay in implementing protocol, in sentence 9, continual of life as usual. The motif of possibility is common in sentences 10 to 15 . It also relates with the lack of certainty in aspects that could and may suggest. 
The Use of Modal Auxiliary Verbs in Reporting Covid-19: A Study of Selected Articles Daily Nation Newspaper

\subsubsection{PREDICTION}

Prediction is used as a modal auxiliary and makes a statement about an event, situation, happening, and act (Quirk et al 2000). Instrumentally, it is used to make prediction which is not definite. The data discussed below show the prediction functions of modals.

16) This will mean a change in lifestyle in painful ways that most Kenyans are yet to experience.

17) The number will grow exponentially.

18) The clinical trials will start in September with a goal to manufacturing....

The modal auxiliary will accounts for 61 instances in the frequency rating and $28.9 \%$ of the total modals use. It has the highest frequency and percentage rating. As a modal will functions to refer to future time and also prediction. Whether for futurity or prediction, the degree of certainty is strong. Will expresses a confident statement. The statements are not necessarily true but they are presented as valid by the article authors. Will is used to indicate prediction in sentences $16-18$.

In sentence 16, it (will) shows that Kenyans in future have to change their lifestyles because of Covid-19. In essence the future time implied in this statement is when the lockdown will be announced. In sentence 17 it (will) indicates that there are chances that the number of infected people will increase as days go by and testing is increased. In sentence 18 the use of will suggests that clinical trials have not started but will start in September which is in the future as the year has not reached September.

The sense of will usually involves animate subjects and some physical actions or events taking place in the future. In the case of sentence 16-18 the animate subjects are Kenyans, Covid-19 patients (referred to as numbers) and the clinical trials respectively. Sentence 16 therefore has the prediction of a change in lifestyle of Kenyans due to the effect of Covid-19, sentence 17, the prediction of numbers growing from infections and sentence 18, the prediction of the start of clinical trials in September.

This meaning of will can be paraphrased as "I predict that..." and the main prediction always has future time reference. Therefore, a change of lifestyle, the growth in numbers and the clinical trials are predicted to occur sometimes in the future.

\subsubsection{OBLIGATION}

Quirk et al. (2000) state that obligation indicates an act that is considered by the speaker to be obligatory in which an agent is obliged to do something. It indicates duty, expediency and expresses condition that makes a statement less direct. It makes formal request or offer. The data below exemplify such modals.

19) We must change our behavior and attitude if we have to cut the transmission of the virus.

20) Social distancing must be observed.

21) As soon as we get the kits...then we will be able to deploy them to increase our testing capability.

22) A clinic will be able to turn that result around quickly, while the patient is waiting.

23) People who are sick and show symptoms should wear masks.

24) Almost seven in every ten Kenyans think that the government should enforce a complete lockdown.

The modals categorized as modals of necessity and obligation include will, must and should. Will has a frequency of 61 and a percentage of 28.9. This indicates that "what should be done" is a concern of the authors of articles on Covid-19 in Daily Nation newspaper. Examples in sentences 21 and 22 is evidence of this. In sentence 21 the government is obligated to provide testing kits for covid-91 while in sentence 22 the clinic testing the suspected cases of Covid-19 are obligated to produce the results quite fast.

Must which has a frequency of 11 and a percentage of 5.2 shows obligation to agent to deal with the issues according to the situation. Thus in sentence 19 it shows that a change of behavior and attitude on the part of the population is necessary for winning the fight against covid -19. Sentence 20 indicates obligation on the part of the people to social distance in order to break the line of infections.

Should according to the data presented has a frequency of 25 and a percentage of 11.8 has the function of imposing an obligation on the addressees. Should in sentences 23 and 24 indicate obligation on sick people to wear 
mask to avoid transmitting the disease to other people and that the government has to duty to lockdown the country in order to reduce the infection rate respectively.

The obligation sense is strong in these cases because they involve urgent responsibilities and instructions that are binding on the persons involved. It is clear in such examples that failure to perform those responsibilities may lead to some devastating consequences hence their urgency. The obligation meaning often involves animate subjects (typically humans) who are capable of performing the actions required by the obligation. Examples 19 and 20 from the data in which must expresses sense of obligation are indicative of animate subjects: We (as the citizens of the country) and the ellipted form of us (as the citizens of the country) the people who must practice social distancing.

\subsubsection{INTENTION}

Quirk et al. (2000) aver that the meaning 'intention' is implied when the circumstances clearly involve a future event that is planned by the speaker. As one of the functions of an article in the newspaper is to inform and report events, the most obvious cases revealed in the corpus show that the writer reports the intention of others. The data used below indicate auxiliary verbs showing intention.

25) This would mean a provision of masks to everyone

26) Health workers would be provided with transport.

27) The ward the boy was admitted would be disinfected.

28) Public service vehicles operators and boda-bodas shall be required to ensure that all their passengers and everybody they carry put on masks to help avert further spread of the disease.

29) We shall embark on the production and distribution of face masks all over the country.

30) As health workers, we are ready to go the extra mile to assist patients, but we will not commit suicide by exposing ourselves to Covid-19 infection while on duty.

31) The current patients will not be affected but no regular cases will be admitted there.

In sentence 25 , would shows the intention of providing masks to everyone, while in sentence 26 , it indicates intention of providing transport to health workers. In sentence 27, would shows the intention to disinfect the ward the boy was admitted into.

In sentences 28 and 29, there is the use of shall to indicate intention. In sentence 28, the intention is that passengers in public transport and boda-bodas wear masks while in sentence 29 , the intention is to produce and distribute face masks all over the country.

Sentences 30 and 31 have the use of will to indicate intention. In sentence 30, the health workers do not intend to commit suicide in the line of duty by exposing themselves to covid-19 infection and in sentence 31 , the government does not intend to admit any new non-covid -19 patient in that facility.

From sentences 25 - 31 it is evident that the article authors are reporting the intention of other people. Even though the events to be taken are not planned by the writers, they chose to identify with the planners in the realization of those goals in their reporting.

\subsubsection{QUASI-LEGAL USE}

Crystal and Davy (1983) note that shall is used to express what is to be the obligatory consequence of a legal decision, whereas Garner (1995) notes that shall should mean 'has a duty to'. But according to Bázlik and Ambrus (2009) shall often expresses prohibition in the negative form. The forms of shall in sentences 32-34 exemplify this.

32) There shall be cessation of all movement by road, rail or air in and out of Nairobi Metropolitan Area and the counties of Kilifi, Kwale and Mombasa.

33) The movement within the Nairobi Metropolitan Area and the counties of Kilifi, Kwale and Mombasa shall continue, subject to the nationwide curfew.

34) Any cargo-carrying vehicle or vessel shall be charged to a single driver and designated assistant all of whom shall be designated as such in writing by the owner of the vehicle or vessel. 
In sentence 32, due to the effects of Covid-19, a curfew is imposed on the towns of Kilifi, Kwale and Mombasa. Due to the curfew, all movements in and out of the towns are prohibited. The cessation of movement is as a consequence of the decision taken to avoid escalation of infection therefore the use of shall indicates a consequence.

In sentence 33, movement within the areas specified is possible, but subject to existing conditions.

In sentence 34, shall indicates 'has a duty to' as noted by Garner (1995). The owner of vehicles or vessels as stated in sentence 34 have the duty to provide written information about the driver and the designated assistant.

\section{CONCLUSIONS AND RECOMMENDATIONS}

This study aimed to analyze the types of modal auxiliary verbs used in reporting Covid-19, the frequency of the modal verbs in newspaper articles about Covid-19 and the functions of the modal verbs. As a result of the study it was found that the newspaper articles used a variety of modal auxiliary verbs in presenting Covid -19 . The modal verbs used are shown in Table 2. This paper however did not discuss the negatives of the auxiliary verbs. It was also not the intention of the paper to undertake a frequency analysis of the various types of functions of the modal auxiliary verbs.

From the discussion it is noted that the most frequent auxiliary verb used is will with a frequency rate of 61 and $28.9 \%$. Will is mostly used to indicate obligation and intention. This is followed by may with a frequency of 28 and $13.3 \%$ respectively. May is used to to indicate ability and possibility. The third is can and should with a frequency $0 \mathrm{f}$ 25 and $11.8 \%$. Can is used to perform the function of ability and possibility whereas should performs the function of obligation.

The modal auxiliary verbs used perform various functions according to Quirk et al's (2000) taxonomy. These functions include ability, possibility, intention, prediction, obligation, and quasi legal use. In terms of these functions and according to the data, obligation, intention and prediction are more salient as the use of will is spread to the three.

\section{SOURCES OF FUNDING}

This research received no specific grant from any funding agency in the public, commercial, or not-for-profit sectors.

\section{CONFLICT OF INTEREST}

The author have declared that no competing interests exist.

\section{ACKNOWLEDGMENT}

None.

\section{REFERENCES}

[1] Ahmad,M. Asim,M, M. \& Mahmood, M, I.(2019). Modal verbs as editors' personal stance markers: An analysis of Pakistani English newspaper editorials International Journal of Sciences and Research Vol. 75 No. 1, 2019. DOI: $10.21506 /$ j.ponte.2019.01.11

[2] Andersen, K. G., A. Rambaut, W. I. Lipkin, E. C. Holmes, and R. F. Garry. 2020. The proximal origin of SARS-CoV2. Nature Medicine 26(4): 450-452. doi: 10.1038/s41591-020-0820-9.

[3] Bázlik, M,. \& Ambrus, P. (2009). Legal English and its Grammatical structures. Praha: Wolters Kluwer CR.

[4] Cheng, Z. K. J., and J. Shan. 2020. 2019 Novel coronavirus: Where we are and what we know. Infection 48(2): 155-163. doi: 10.1007/s15010-020-01401-y.

[5] Crystal, D., \& Davy,D. (1983). Investigating English Style. Harlow: Longman.

[6] Downing, A. \& Locke, P. (1992). A university course in English grammar. Hemel Hempstead: Phoenix ELT.

[7] Garner, Bryan A. 1995. A Dictionary of Modern Legal Usage. New York: Oxford University Press.

[8] Fowler, R. (1991). Language in the news: Discourse and ideology in the press. New York: Routlege. 
[9] Halliday, M.A.K. (1970). Language structure and language function. In J. Lyons (Ed.), New horizons in linguistics (pp.140-165). Harmondsworth: Penguin.

[10] Hodge, R. and Kress, G. (1993). Language as ideology. (2nd.). New York: Routledge.

[11] Huddleston, R., \& Pullum, G. K. (2002). The Cambridge grammar of the English language. Cambridge: Cambridge University Press.

[12] Huddleston, Rodney \& Pullum, Geoffrey K. (2005). A students introduction to English grammar. Cambridge: Cambridge University Press

[13] Hyland, K. (1994). Hedging in Academic Writing and EAP Textbooks. English for Specific Purposes, 13(3), 239 256. http://doi.org/10.1016/0889-4906(94)90004-3

[14] Leech, G. (1987). Meaning and the English verb. London: Longman.

[15] Leech, G. and Coates, J. (1980) 'Semantic indeterminacy and the modals.' In: Quirk, R., Greenbaum, S., Leech, G. and Svartvik, J. (eds) Studies in English Linguistics. London: Longman. 79-99.

[16] Ling, Y. S. C. (2016) The Use of Modal Auxiliary Verbs in Horoscope: Issues in Language Studies (Vol. 5 No. 2 - 2016)

[17] Logogye, C. (2016) Modality Versus Performativity in Ghanaian Newspaper Editorials International Journal of English Language and Linguistics Research Vol.4, No.5, pp.15-34, August 2016

[18] Ngoge,T.G. (2014). A Comparative Study of Print and Online Media Content in Kenya: A Case of 'Daily Nation' Newspaper. Unpublished MA Thesis. University of Nairobi

[19] Palmer, F. R. (2007). Mood and Modality. Beijing: World Book Publishing Company.

[20] Palmer, F.R. (1990). Modality and the English Modals.London and New York: Longman York

[21] Quirk, R. S.\& Greenbaum, S. (2000). A University grammar of the English language. Delhi: Pearson Education.

[22] Quirk, R. S., Greenbaum, S., Leech, G., \& Svartvik, J. (1985). A comprehensive grammar of the English language. Harlow: Longman.

[23] Radford,A., Atkinson, M.,Britain,D.,Clahsen, H. \&Spencer, A.(1999). Linguistics: An Introduction. Cambridge: CUP.

[24] Sadia,S \& Ghani,M. (2019) Modality in Editorials of Pakistani English Newspapers: A Corpus Based Study. International Journal of English Linguistics; Vol. 9, No. 1; 2019.

[25] Tognini-Bonelli, E. (2001): Corpus Linguistics at Work (Amsterdam/Philadelphia: Benjamins).

[26] Torabiardakani,N. Khojasteh,L, \& Shokrpour,N.( 2015). Modal Auxiliaries and Their Semantic Functions Used by Advanced EFL Learners. Acta Didactica Napocensia Volume 8, Number 2, 2015

[27] World Health Organization. (2020). Coronavirus disease 2019 (COVID-19) situation report - 59. https://www.who.int/docs/ default-source/coronaviruse/situation-reports/20200319-sitrep- 59-covid19.pdf?sfvrsn=c3dcdef9_2.

[28] Yang, X. (2018). A Corpus-based Study of Modal Verbs in Chinese Learners' Academic Writing English Language Teaching; Vol. 11, No. 2; 2018 